\title{
Diminishing local Languages in the Era of Globalization: A Case Study of Pakistan
}

\author{
Samreen Bari \\ Research Scholar Ph.D \\ Department of International Relations, \\ University of Karachi \\ paesthetics@yahoo.com \\ Sidra Ahmed \\ Lecturer \\ DHA Suffa University, Karachi \\ sidra.ahmed@dsu.edu.pk \\ Prof. Dr Shaista Tabassum \\ Department of International Relations \\ University of Karachi \\ shaista@rocketmail.com
}

\begin{abstract}
The transmitted cultural and nationalistic values, morals and ethics, are truly the essence of any nation which makes them unique and exclusive. The permanence, relevance and practice of cultural traditions, values and mores, are social ideals that have existed for centuries are passed down to every generation. They are one of the very few things that have stood the test of time.
\end{abstract}

Language is the backbone of all cultures. It is the most distinguished skill, a present and an art presented to an individual by society. We sense, impart, express, pass on, dream, and manage our day by day lives, with the guide of words that are fathomable and important to us. The skeleton of culture is deficient and can't get by without the solid help of language because of the unavoidable, uncontrollable and massive flow of foreign cultures as a result of Cultural globalization are considered as the most vital reason that is diminishing the importance of local culture and local languages. As Pakistan is a culturally rich country, the local, interactive dialects of the heterogeneous communities have their own charming 


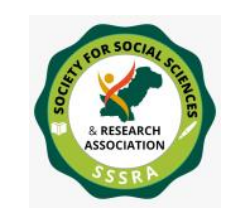

Diminishing local languages in the era..

fascination, but due to heavy influence of Globalization these local languages are diminishing.

Key Words: Culture, Globalization, Pakistan, Language, Diminishing

\section{Introduction}

'Globalization'- a fashionable, fascinating, and a captivating, yet equally controversial, and debatable and questionable word - is the most widely used term for one of a disputable topics of this Century. It is also one of the most frequently discussed economic, political, social and cultural phenomenon of the twenty-first century. Various Scholars emphasized on different aspects yet their main focus are interdependencies, interconnectivity, homogeneity, even opportunities, capitalist economy, borderless politics, cultural fusion hence negating any observance to the physical and soft boundaries of states.

This process has been playing a dynamic role in changing the lifestyles of common people, either living in far off places of Africa or enjoying busy lives in cosmopolitan cities of America, because of the development as well as the accretion of release of people, ideas, values, cultures, beliefs and flows of capital beyond and across national borders. This process involves internationalization and cosmopolitanism, assimilation and fragmentation, universalization and homogenization, which is basically unavoidable dialectical mechanism comprising of speedy social, cultural, political and technological change. Therefore, these changes are taking place simultaneously in different directions, at varied scales and in diverse territories, proving that all these fields, scales and scenarios are interdependent and interconnected.

Globalization is the main agent and a vital driving force in reshaping the contemporary world. The fused and transformed cultural dimensions have given a new scenario and new shape to the indigenous national culture.

Globalization has multifaceted dimensions (economic, political and cultural dimensions) actually it is Cultural globalization that outlines other faces of globalization. Cultural globalization is a process that is changing, influencing or transforming the everyday life through diffusion of lifestyle, preferences, ideas and commodities around the world. Globalization is a process that includes the causes, course, and consequences of transnational and trans-cultural integration of human and non-human activities (Al-Rodhan, 2006). Social interdependencies and exchanges do not require the formal representation of the states; individuals can follow, organize, 


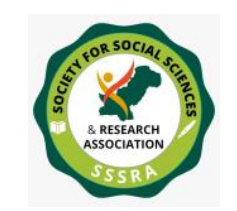

Pak. Journal of Int'L Affairs, Vol 3, Issue 2 (2020)

Diminishing local languages in the era...

share and maintain their relationships, feelings and events freely: as this is a borderless or a de-territorialized world now.

\section{De-territorialization}

The concept of de-territorialization was introduced by the French Philosophers Gilles Deleuze and Felix Guattari (Deleuze \& Guattari, 1972) . They used this term to refer the fluid, dissipated and schizophrenic nature of human in modern capitalist culture. Most commonly this term is used to discuss the process of cultural globalization. It refers to the fading of ties between culture and place, diminishing of cultural values from a specific place with the passage of time. When a culture is going through the process of change it is always because of transcendence and domination of other attractive cultural practices. Cultural distancing from the native community accelerated when people after the exposure of alien media extend and expand their imagination. Hence it becomes difficult for a local culture to retain its identity. Arjun Appadurai (Appadurai, 1990) considered deterritorialization as a central force of globalization. As, globalization theory, apparently started, with the ambitions of the globalization of economy, politics and culture and the sweeping away of the importance of territorial boundaries and national economies, states and cultures (Martell, 2007).'De-territorialization' is a disputable word. This term emphasizes that in a globalized world, numerous social happenings and exchanges can take place without geography functioning as a restraint or limitation.

The growing massive waves of globalization prove that the calculable perception of space has been elongated to the globe, therefore, cultural globalization through the process of de territorialization is not only promoting the global culture hence relocating the people from their own cultural values and also minimizing the spirit of Nationalism. Deterritorialization in actual projected the concept of the loss of the "natural" relation between culture and the social and geographic territories (Cancilini, 1990) .Globalized world is experiencing that the culture is becoming more and more de territorialized and is absorbing and is being influenced and being penetrated by elements from other cultures. This ends in cultural contamination, cultural pluralism and hybridization. It is becoming more difficult to study culture of diffusion. Apart from it and at the same time, it is becoming more important to study it because of its massive influence on consumer behavior and its direct implications on security and on National character of the nations. Cultural globalization is providing and concentrating on a system that isn't subject to customary, political, financial, social and geographical limits. (Albrow, 1990) Apart from economic, social and political issues a fundamental 


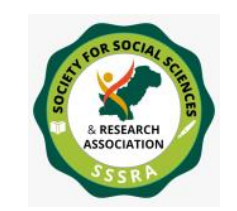

Diminishing local languages in the era..

hypothesis in the globalization discussion is that globalization fundamentally changes the association between the place where we live and our cultural experiences and identities.

Diffusion of practices, values, morals, ethics, principles and technology lays great influence on people's lives worldwide. Globalization is a transformation not a culmination and the shift to a new period rather than the apogee of the hold (Albrow, 1990). Cultural globalization is actually a soft power different from economic influences or the use of force. It works like a magic and through this method no military or economic intervention is needed to be able to influence other countries. In a way it is a split and rule technique. So, the question again arises that whether this situation is acceptable as a form of "peace" or it is a serious form of disparity, vulnerability and exploitation (Onuf, 2017) (Galtung, 1969). The cultural globalization can be imposed and projected through persuasive methods like the support of mass media, film industry, tradition, fashion, internet or language. These persuasive methods help to strengthen the cross border relationship, increase interconnection, making people across the globe more interdependent on each other. Cultural globalization works through comparatively less transparent and unseen channels, as well as lobbying through powerful political and non-political organizations.

The most important and vital indicators of national identity is the observance and presentation of specific values amongst its people. The cultural and nationalistic values transferred from one generation to other are actually the specific and exclusive component that made them distinctive and unique. Through the continuity and practice of culture and traditions, values and mores; are social paradigms that repetitively alive from the past and even towards the future. Values are the basis of social coherence and unity; since lack of values would conclude weak society structure and the blowout of psychological disorders at the level of individuality (Al-Johari, 1991). It is assumed that globalization is responsible in weakening this social coherence and unity as due to compression of the world and permeable boundaries; globalization is adversely affecting the state's cultural values.

\section{Language}

If globalization flourishes, the world might finally develop mono-lingual. Earlier or far ahead, possibly in a new millennium, there could be just only one world language the English language. Rest of the languages may be condensed to vernacular 


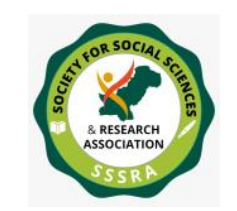

Pak. Journal of Int'L Affairs, Vol 3, Issue 2 (2020)

Diminishing local languages in the era..

position. This tendency has now been perceived to be likely consequence of the globalization of mass media (Waters, 1995).

Language is the individual's earliest acquisition. It is considered as the secret territory, it is used to define the distinctiveness of a nation, and hence language is considered as the symbol of national identity. Not only it is considered as the symbol of cultural identity but it is the vital source and a tool for transmitting values, beliefs, history and the overall pattern of life from one generation to other. In the absence of a binding force that is "language" people would lose their cultural as well as geographical identity. The planned struggles to preserve and protect ethno cultural uniqueness, frequently represented by the language related with the group, establish nationalism and are considered as a drive that can encourage the spread or conservation of a language. (E.Lewis, 1982)

As globalization enforces interconnectedness and interdependence of the individuals, nations, corporate and social institutions of the global village hence the importance of lingua franca is increasing day by day. The proponents of universal language emphasize that lingua franca help us to develop the ability to communicate with the individuals of the other cultures and also the knowledge and understanding of the foreign languages enable us to become a citizen of the global world and to perceive new horizons.

The world's total population is about 7.6 billion and nearly there are around 7000 different forms of mother tongues or languages. Surprisingly out of these 7000 different languages only 100 languages are considered as the official language of a state (UNRIC, 2018). Ethnologue an organization that exclusively working and is dedicated to research for language intelligence claimed that around 7117 languages are spoken the world over and the unpleasant truth is that $40 \%$ of these dialects are reducing or are ceasing to exist (Eberhard, Ethnologue, 2020). Disappearance or a death of a language within its cultural framework resembles like burning the history of a particular and distinct culture, corroding its folk tales, forgetting its religious parameters, and its colorful literature, the mindset, approach and vision of its scholars and that of the common people.

"UNESCO unveiled its first comprehensive and online database of the world's endangered tongues. According to its team of specialists, there are around 2,500 languages at risk, including more than 500 considered "critically endangered" and 199 which have fewer than 10 native speakers (Davies, 2009)". "It's estimated that there 


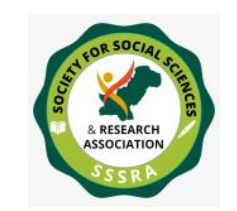

Pak. Journal of Int'L Affairs, Vol 3, Issue 2 (2020)

Diminishing local languages in the era...

were approximately 10,000 languages spoken only a couple of hundred years ago" (Ettlinger, 2014). The disappearance of local language means the disappearance of a particular culture and it means the disappearance of a particular nation. Based on the data from Ethnologue, Africa speaks 2,144 languages. The Americas still speak 1,061 languages while Asia still speaks 2,294 languages. The Pacific Islands (including Australia and New Zealand) have 1,313 languages while Europe only speaks 288 (Eberhard, Languages of the World, 2020).

"When a language dies out, part of the world's tapestry of cultural heritage fades out with it. Each language has its own peculiarities and characteristics through which it conveys meanings and connects its speakers to a wider society and a cultural community. Languages are not merely sounds, words and grammatical rules - mother language is part of our identity, heritage and worldview, and as such it is invaluable (Cancilini, 1990)".

It is assumed that around 300 million people from the overall world population that is roughly 5 percent of the overall global inhabitants preserve a strong distinctiveness as adherents of an aboriginal culture, embedded in history and language, emotionally involved by mythos and remembrance to a specific habitation on the planet. Although their population sizes are minor, these cultures have contributed for almost 60 per cent of the world's languages and jointly symbolize over half of the scholarly inheritance of humanity. All over human history, almost of ten thousand languages existed. At present, almost six thousand still vocalized, completely half are not being taught to children, that means, they are now dead, and simply three hundred are vocalized by further a million people. Linguists considered that around 600 languages are established and secure. But no one knows that by the next century, probably this number may be intensely condensed (Davis, 2001).

This is the brutal reality and the center need of the financial improvement of a capitalist society to have a solitary and worthy language. The overall financial network, complicated, integrated yet effective software networks, MNC's, TNC's, NGO's all require a general or a globalized language. Joseph Nye's concept of 'Soft Power' can absolutely clarify the impact and requirement of homogenous culture in context of cultural imperialism and language dominancy.

This is the harsh reality and the core need of the economic development of a capitalist society to have a single and acceptable language. The financial framework, highly complicated yet effective software, multinational companies. NGO's and the 


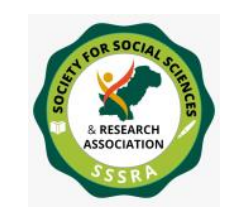

Diminishing local languages in the era..

globalized communication network all require a universal or a globalized language. Joseph Nye's idea of 'Soft Power' can certainly elucidate the answer of language imperialism. Consequently, we can claim globalized language may be destructing or diminishing or threatening the local languages of the developing and under developed nations.

Vast number of languages are being replaced by the other most commonly used languages of the region such as English in the U.S. or Spanish in Mexico (Woodbury, Linguistic society of America, n.d.). It is immensely important to preserve these endangered languages otherwise by the next century these endangered languages will be extinct as soon as their last speaker will die as because of the way toward the homogenous world the new generation is not taking interest in learning these languages.

Absolute extermination or genocide is one reason of language disappearance. When European raiders eliminated the Tasmanians in the early 19th century, an unidentified amount of dialects disappeared. It is a fact that languages vanished when a community finds itself under pressure to assimilate with a larger or more dominant group (Blench, 2008). Usually people acquire the foreigners' language when they perceive it is beneficial; this is what happened in Greenland, a terrain of Denmark, where Kalaallisut is spoken along with Danish. However the community is under pressure to abandon its mother tongue and even its ethnic and cultural individuality. Another example is of the situation for younger speakers of Native American languages, they were penalized for communicating their innate lingos at boarding schools (Rajeev, 2018).

Formerly strong lingo dies for the reason that its speaker transfer loyalty and adherence to that of a strong, more acceptable, more fashionable, more influential grouping of people. Unsurprisingly, there are two culturally rich countries where the danger is maximum are India and Brazil, which are experiencing speedy trade and industry transformations. "[These trends] often bring about the loss of traditional ways of life and a strong pressure to speak a dominant language that is - or is perceived to be necessary for full civic participation and economic advancement," (UNESCO, 2017)

In a globalized world the importance of English language cannot be undermined. It is considered as the corporate language of the world it is also the second most spoken language of the world. "English has run rampant across the globe... people want to 


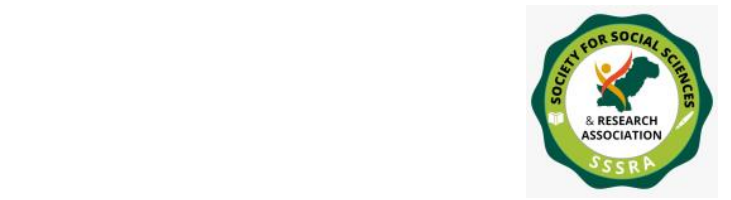

Diminishing local languages in the era..

speak English, because it is the language of advertising, blockbuster movies, and pop music, as well as a vital tool for success. (Dubrow, 2002)"

People all across the world prefer to use the words of English language so that they would be able to acquire good positions in corporate circle. The over exposure and dominance of English language has some negative effects as well as it is disassociating people from their own native languages. The use of English language or any other global language at the cost of local languages threatens smaller ones.

\section{Impact of Cultural Globalization on Local Languages}

According to Cambridge dictionary language is "an organization of communication consisting of sounds, words, and grammar, or the system of communication used by people in a particular country or type of work (Press, n.d.)". Therefore we can say that the demise or loss of a language is the demise of a particular era, loss of a particular segment of history, death of a culture, the ethical vanishing of a country, subsequently the constant battle for the restoration, engendering, and move of UNESCO (UNESCO, 2017) admitted that: "Languages are threatened by external forces, such as military, economic, religious, cultural or educational suppression or by internal forces, such as community's negative attitude towards its own language".

Cultural globalization in the form of a massive wave of Western languages are actually minimizing the importance of the local languages of developing nations. We can say that the expansion in globalization implies the loss of mother dialects. People find them at ease to carry out business activities and correspondence with the more flourishing or Western languages, not of their own culture, because of this reason the local languages are dying out.

\section{Endangered Languages of Pakistan}

Pakistan is a culturally rich and diversified country. Ours is a multilingual country with six major and seventy two minor or local languages (Rehman, Language \& Childern's Education In Pakistan., 2010) whereas as per ethnologue (Manan, David, \& Dumanig , 2015) there are 77 local languages

In Pakistan the government and speakers of local languages are not at all interested to promote the native languages to their next generation. Since inception, the dominant 


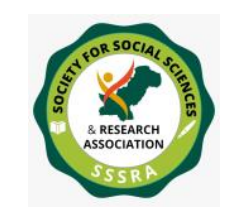

Diminishing local languages in the era..

ethnic groups have been trying to suppress the other recessive or partially small groups through economic supremacy, education policies and cultural dominancy. Urdu is officially the National language even though it is the mother tongue of only $7.57 \%$ of the urban population and can be termed as the local lingua franca whereas English is the official language. It is unfortunate that this multilingual country's official language is the one that has been adopted from its 'Colonial Masters'. It is commonly used by those powerful and influential people who are actually controlling the system of the government, judiciary, armed forces, education, media, etc. English has become a status symbol or a brand of upper class families. It is a symbol of sophistication and power. Due to the influence of Capitalism, English is already being considered as the de facto lingua franca or global language. An estimated $85 \%$ of International Organizations use English as their Business Language (Barančicová \& Zerzová, , 2015).We cannot deny the importance of English, but not at the cost of other languages. Local traditions have the power to allure, fascinate and mesmerize other cultures.

\section{Aer}

Is a language of a rural area of Sindh, Some people of Aer descent are reported to be living in the Nawabshah area in Sindh, but their culture is different. Aer is spoken by only a couple of hundred people and hence is a 'threatened' language. It is a language verbally expressed in the rustic zones of Sindh, quite Hyderabad, Kot Ghulam Muhammad and Kunri. A few people of Aer drop are accounted for to be living in the Nawabshah region in Sindh, however their way of life is unique. Aer is spoken by just two or three hundred individuals and consequently is a 'compromised' language.

To sum up well into one thing that Aer is the language that has the taste of three different dialects i.e, Indo-Iranian dialect, Indo-Aryan dialects, Indo European dialects. (Product, n.d.) Globalization of cultures and lingua franca can be considered as the most important factor behind the extinction of language. Political and economic factors also play a role in the downfall of Aer language. These two factors have worked together. As English became the ladder or route way to success, it became important for everyone to learn English to compete for jobs and other needs. And as Urdu became a national language it was important for the people to know Urdu language as well. With these changes, people stopped learning and using and promoting Aer language and that is exactly from where the downfall of the language came. 


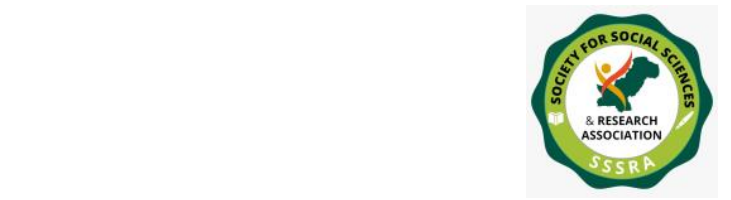

Diminishing local languages in the era..

Aer had been rich in its own times when people of Sindh used to communicate in this language. But with time and globalization, people forgot the usage or limited their attempts at speaking the Aer language. From there, the downfall of Aer language came and from there it reached the list of all those endangered languages that are on their brink of losing their identities. As per etymologists, an undermined or imperiled language is one whose speakers cease to exist or move to different dialects and the language is at risk for dropping out of utilization. Some Aer words propose conceivable chronicled association with Rajasthani dialects, Gujarati and Kuchchi, as well. (Parekh, Some endangered Pakistani languages, 2018)

\section{Badeshi}

Badeshi is an Indo-Iranian language of the Chail Valley. Only few hundred native speakers of this language are alive. Therefore it is considered as the endangered language of Pakistan. (Rehman, 2008).It is a 'dormant' language. A language that has very little capable speakers and is used for narrow purposes is known as dormant language. This language is spoken in upper Swat, as in Tret and Bishigram in Khyber Pakhtunkhwa.It is also spoken in areas near Mansehra and Alai. Some residents claim their families had migrated from Badakhshan in Afghanistan and that is why the language is also called Badakhshi. (Desk, 1st March 2018)

Agreeing with Parekh, Ahmed said: "The survival of small languages has a direct connection with the economy. When a Torwali- or Badeshi-speaking youth has to be fluent in English or Urdu, or at least in a dominant regional language for education and employment, their attention for their mother tongue will automatically reduce (Parekh, Some endangered Pakistani languages, 2018)."

\section{Burushaski}

Burushaski is an isolated language completely different spoken in Hunza, Nagar districts and Ghizer district in the Yasin Valley in Gilgit-Baltistan. It is unrelated to any of its neighboring languages that is Dardic and Iranian languages. A German Professor named, Berger conducted a thorough and insightful investigation on the language in the late 1950s and 1960s.

Based on his own investigation, he also compiled a book on Burushaski grammar in 1974. He conducted broad research on the Yasin accent and Gilgit-Hunza accent of this language. Other scholars also conducted and published their research on this language so there are dozens of books available on Burushaski's grammar, vocabulary, phonetics and semantics. In spite of all this research and investigation, the nature and 


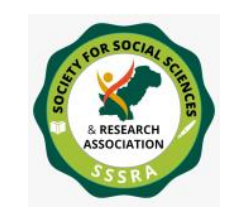

Pak. Journal of Int'L Affairs, Vol 3, Issue 2 (2020)

Diminishing local languages in the era..

foundation of Burushaski language remains unidentified as it has disregarded all categorizations and linguists still consider it an unclassified language (Parekh, Burushaski is a strange language, 2010).

\section{Chilisso , Dameli}

Chilisso, a Dardic script that is now moribund. It is spoken in dispersed villages on the right bank of the Indus River among the majority Shina-speaking community on the eastern side of Khyber Pakhtunkhwa districts of Kohistan. (Mock, n.d.). Dameli is also a Dardic language spoken in Damel Valley, situated in southern Chitral, between Drosh and Arandu, around $20 \mathrm{~km}$ south of Drosh (Mock, n.d.).

\section{Bhaya}

It is another endangered language as only seven hundred speakers of this language are alive. It is spoken in Sindh, especially in and around Hyderabad, Mirpurkhas, Kot Ghulam Muhammad and Khipro. Bhaya is also the branch of an Indo-European, IndoIranian, Indo-Aryan language and has verbal connections with Marvari and Malvi. (ELP, n.d.).

\section{Domaaki}

Domaaki is another moribund language of Hunza. Although the speakers of this language are settled in Mominabad (erstwhile Bayrishal) village in Hunza however it was originated from Gilgit-Baltistan region of Pakistan.

Domaki people were attached mainly with two professions for centuries they were mainly musicians and blacksmith. That is why even today the musicians in Punjab are usually called "dom" or "doom". Politically, there were isolated and there was an absolute detachment amongst the customary power structure and the Domaaki speaker. Because of this reason the Mir of Hunza banned them from communicating in the Brushashki language. Doms are usually not permitted to marry outside their casts. The disappearing of Domaaki language throughout the alteration of society from tradition to modernity displays the mismanagement of the society of Gilgit-Baltistan to handle the challenges of globalization.

The number of Domaaki speakers are drastically reducing. In 1990, only 500 speakers were alive. Now it is assumed that only few people of older generation can understand this language but they are not transferring this language to their new generations as they don't speak their language with their new generation. With the death of the old group Domaaki will also be buried into the dust. (Dad, 2011) 


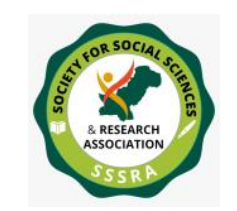

Diminishing local languages in the era..

Gawri

This is northern language of Pakistan which is also called kalami. This is one of the many Kohistani nearly dying languages of Pakistan which are extinct by dominant language of that area that is Pashto. According to many linguistic description Gawri language was arrive in 18century. Many languages like Gawri, Torwani and Indus Kohistani are still around their natives still used to spoke these languages, but the number of their natives decrease by time so, we can't say these languages are entirely out of danger. George Grierson, the editor of the linguistic survey of India was notice in his days, two sizeable villages almost complete shifted from Gawri to Pashto. So, that people about the age 30 to 40 years are still speak Gawri but the younger generation are not. Around 100,000 people in northern area of Pakistan spoken this language.

The people of Gawri language used to cultivate potato in past some thirty or forty years ago, potato was introduced as a cash crop and adopted by almost all farmers. One can see a few other cash crops as well, such as turnip and cabbage. By the time due to increase in population they forced to look for other crops too and moves Islamabad , Lahore , Karachi for this purpose they learn other language and when they seek no benefit in spoken of their native language they stop speaking in their native language.

In the past people were not educated, but now a days these people start education which increase their productivity but the drawback is the downfall of their native language because in school and other educational institutes prohibited to talk in their native language and forced to learn Urdu and English which is our official and national languages so, they focused on them, as a result student forget their native language intentionally. (Sagar, 2018)

\section{Kalasha}

A Dardic language. The Kalasha are concentrated in several small valleys on the west side of the Chitral River south of Chitral town: in the Rumbur, Bumboret, Birir and Urstun within Valleys of district Chitral in Khyber Pakhtunkhwa. There are only 5000 number of speakers left. (unesco.org, n.d.)

\section{Yidghaa}

Another endangered language of Chitral with only 6000 speakers it is assumed that due to the lack of interest of the native speaker in their mother tongue this language will cease to exist in nearly 10 years. (Decker, 1998). 


\section{Impact of globalization on National languages of Pakistan}

M V Nadkarni (1984) identifies three functions: 1) the routine or daily communication among the people of the same ethnic group or communication with in-group 2) interaction and verbal communication to perform commercial or other societal activities with people of the out-group and 3) highly professional and up to date transfer of information by using corporate language.

Logically speaking we can conclude that in Pakistan the language of the people of the small or different ethnic or linguistic group satisfies the primary role, Urdu the second one; and English undoubtedly is the communication tool to perform the third function.

\begin{tabular}{|c|c|c|c|c|c|c|c|c|}
\hline \multirow[b]{2}{*}{$\begin{array}{l}\text { Administrative } \\
\text { Unit } \\
\end{array}$} & \multicolumn{7}{|c|}{ POPULATION BY MOTHER TONGUE } & \multirow{2}{*}{$\frac{\text { (In percent) }}{\text { Others }}$} \\
\hline & & Urdu & Punjabi & Sindhi & Pushto & Balochi & Saraiki & \\
\hline \multirow[t]{3}{*}{ Pakistan } & & 7.57 & 44.15 & 14.1 & 15.42 & 3.57 & 10.53 & 4.66 \\
\hline & Rural & 1.48 & 42.51 & 16.46 & 18.06 & 3.99 & 12.97 & 4.53 \\
\hline & Urban & 20.22 & 47.56 & 9.20 & 9.94 & 2.69 & 5.46 & 4.93 \\
\hline \multirow[t]{3}{*}{ Khyber Pakhtunkhwa } & & 0.78 & 0.97 & 0.04 & 73.9 & 0.01 & 3.86 & 20.43 \\
\hline & Rural & 0.24 & 0.24 & 0.02 & 73.98 & 0.01 & 3.99 & 21.52 \\
\hline & Urban & 3.47 & 4.58 & 0.11 & 73.55 & 0.03 & 3.15 & 15.11 \\
\hline \multirow[t]{3}{*}{ F A T A } & & 0.18 & 0.23 & 0.01 & 99.1 & 0.04 & - & 0.45 \\
\hline & Rural & 0.18 & 0.18 & 0.01 & 99.15 & 0.04 & - & 0.43 \\
\hline & Urban & 0.18 & 1.85 & - & 97.00 & * & - & 0.96 \\
\hline \multirow[t]{3}{*}{ Punjab } & & 4.51 & 75.23 & 0.13 & 1.16 & 0.66 & 17.36 & 0.95 \\
\hline & Rural & 1.99 & 73.63 & 0.15 & 0.87 & 0.90 & 21.44 & 1.02 \\
\hline & Urban & 10.05 & 78.75 & 0.09 & 1.81 & 0.14 & 8.38 & 0.78 \\
\hline \multirow[t]{3}{*}{ Sindh } & & 21.05 & 6.99 & 59.73 & 4.19 & 2.11 & 1.00 & 4.93 \\
\hline & Rural & 1.62 & 2.68 & 92.02 & 0.61 & 1.50 & 0.32 & 1.25 \\
\hline & Urban & 41.48 & 11.52 & 25.79 & 7.96 & 2.74 & 1.71 & 8.80 \\
\hline \multirow[t]{3}{*}{ Balochistan } & & 0.97 & 2.52 & 5.58 & 29.64 & 54.76 & 2.42 & 4.11 \\
\hline & Rural & 0.21 & 0.43 & 5.27 & 32.16 & 57.55 & 1.87 & 2.51 \\
\hline & Urban & 3.42 & 9.16 & 6.57 & 21.61 & 45.84 & 4.16 & 9.24 \\
\hline \multirow[t]{3}{*}{ Islamabad } & & 10.11 & 71.66 & 0.56 & 9.52 & 0.06 & 1.11 & 6.98 \\
\hline & Rural & 2.33 & 83.74 & 0.08 & 7.62 & 0.02 & 0.3 & 5.91 \\
\hline & Urban & 14.18 & 65.36 & 0.81 & 10.51 & 0.08 & 1.53 & 7.53 \\
\hline
\end{tabular}

Source : (Statistics, POPULATION BY MOTHER TONGUE, 21-02-2020)

It is a common traditional practice in several countries that people, on a routine basis, speak several languages. They prefer to speak their mother tongue at home, national language in social gatherings, an official language at workplace, and a different 


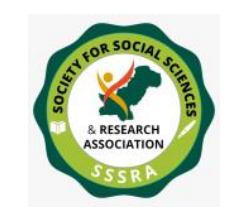

Diminishing local languages in the era..

language for religious purposes. But here in Pakistan, the speakers of local languages are not inclined to transfer the language legacy to their next generation. Not only local languages are being treated like this but also the national languages like Urdu, Punjabi, Sindhi and Pashto are facing discriminatory behavior from their own native speakers. Now majority of the urban population is willing to admit their children in English medium schools, they like their children to watch English movies and read English novels and listen English songs. Young generation are also showing their inclination to learn other foreign languages like French, Chinese and German but the trend towards reading, listening and speaking national languages is declining as it is evident with the collected data.

\section{Education and Media}

Quite amazingly, we have even failed to provide entertainment to the people in their native language, from Pakistani cinemas Hollywood movies are earning huge amounts. Foreign film Industry is playing a prominent role in creating huge impact and invading the minds of the common people, one of the greatest examples of this invasion is Hollywood Film Industry, which produces a variety of films throughout the year. Top 5 opening films at the Pakistani box office are:

1.Avengers Endgame: 4.5 crore

2.Sultan: 3.4 crore

3.Fast 8: 3.23 crore

4.Sanju: 3.2 crore

5.Jawani Phir Nahi Ani 2: 2.9 crore

Source: Khawar, Z. (2019, April 27). Galaxy lollywood. Retrieved Aug 17, 2020, from http://galaxylollywood.com/2019/04/27/box-office-avengers-endgame-shattersrecords-in-pakistan/

We conducted an interview with Mr. Rashid Khawaja a prominent media professional, drama and film producer and also the CEO of Entertainment Pk informed us that the apparent figures of the box office hits do not reflect the overall picture of the film industry as there is a grey channel through which people are watching Hollywood and Bollywood movies. Hence the viewer ship is far more than this. 
Films Released in the Country by Language

\begin{tabular}{|c|c|c|c|c|c|c|}
\hline \multirow{2}{*}{ Year } & \multicolumn{6}{|c|}{ Number of films released } \\
\hline & Total & Urdu & Sindhi & Punjabi & Pushto & Sariaki/ Gujrati \\
\hline 2008 & 35 & 7 & -- & 12 & 16 & -- \\
\hline 2009 & 23 & 5 & - & 9 & 9 & - \\
\hline 2010 & 18 & 3 & -- & 7 & 8 & - \\
\hline 2011 & 24 & 6 & - & 4 & 12 & 2 \\
\hline 2012 & 22 & - & - & 6 & 16 & - \\
\hline 2013 & 31 & 8 & - & 5 & 18 & - \\
\hline 2014 & 42 & 15 & 3 & 8 & 14 & 2 \\
\hline 2015 & 51 & 22 & 3 & 8 & 14 & 4 \\
\hline 2016 & 64 & 34 & 2 & 9 & 13 & 6 \\
\hline 2017 & 44 & 33 & - & 3 & 8 & -. \\
\hline 2018 & 25 & 15 & - & 2 & 8 & -- \\
\hline
\end{tabular}

Source: (Statistics, Films Released in the Country by Language, 2020)

The interactive languages of the heterogeneous groups have their own charismatic attraction, but due to the influence of Globalization, these languages are slowly and gradually becoming extinct. The minor and local indigenous languages are not being promoted in any forum. All mainstream domains like education, media, films, business or government offices promote English language in their routine business. None of the local languages are being taught at School level except for Sindhi and up to some extent Pashto. Although UNESCO recommended its member countries to provide at least private education in the mother tongue despite knowing the fact our governments have not shown any interest and have not taken any steps in this regard. 
“...if you speak to a child in a language he doesn't understand, the language the parents don't speak, the community does not communicate in, a language the teachers sometimes even have serious challenges in, you set the whole learning process back. Don't worry that somebody's child is speaking English before yours that is not what matters. What matters is that the child is taught in a language the child knows... there is nothing wrong with our languages. There's everything good in them" (Arku, 2014). The following table of registered periodicals and newspapers by language clearly indicates that a certain class and capitalists are trying to popularize English not only as official language but we are providing education to our future generation in the foreign language that is not understandable for them.
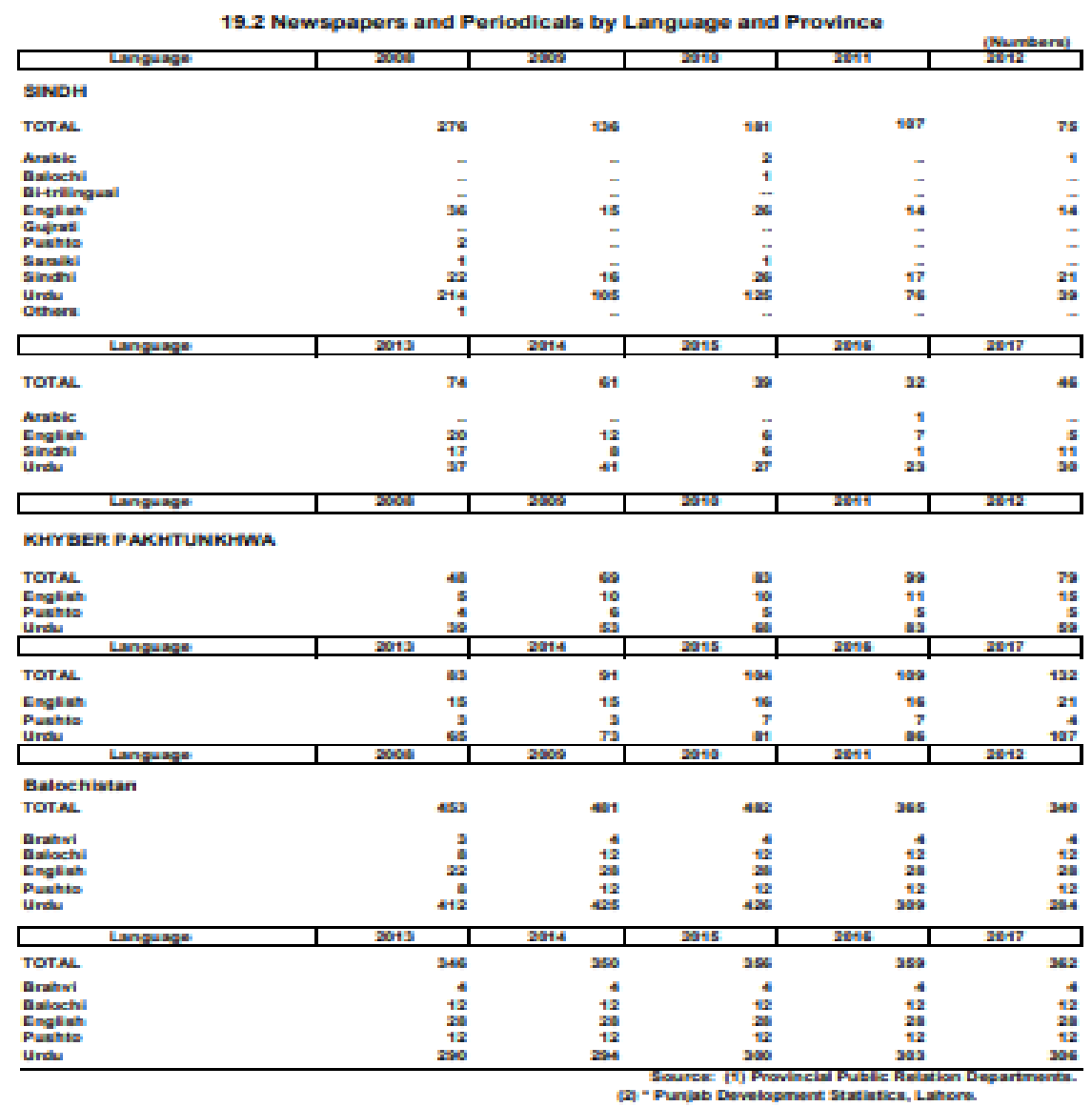

Source: STATISTICS, P. B. (2017). Newspapers and Periodicals by Language and Province. Islamabad: GOVERNMENT OF PAKISTAN. 


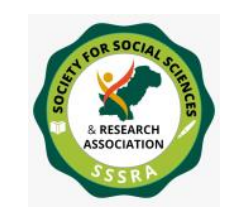

Diminishing local languages in the era..

It should be the ultimate responsibility of government to promote and apply the multilingual education system so that education can reach to the doorstep of each and every Pakistani citizen. Through drastic improvements in education system and by providing education all the way through regional or local languages the literacy rates can be increased, we can introduce more skilled workers and in this way the economic activity will flourish at the same time, propping up the cultural value of diverse traditions of Pakistan.

\section{Interviews conducted with Government and Private Teachers}

We conducted several interviews with various language teachers and almost all of them agree that neither government nor parents are interested in inculcating interest for local languages in their children.

Mrs. Fehmina Azwer an experienced Urdu teacher of a renowned School in Karachi (Mama Parsi Girls Sec School) explained the treatment with Urdu language with these words:

"As Urdu was my favorite subject since my school days, my parents also encouraged me and introduced the poetry and literature of Ghalib, Deputy Nazir Ahmed, and Iqbal during school days. But after the completion of M.A (Urdu) it seems almost impossible to get a relevant job. After consistent struggle of six months I finally got a job in a reputable school as an Urdu teacher but I was shocked when I came to know that the salary package for Urdu teachers is far less than English or Math teachers. Another problem is the easy going strategy of Parents as they take least interest in this subject particularly hence they don't want their children to invest more time to study Urdu. They don't even try to seek guidance and to know the performance of their kids during Parent- teacher meetings".

A Senior Government Urdu teacher Mrs. Rehana Zuberi showed her grief and discontent over the attitude of students and government with Urdu and Sindhi as students consider it useless to study these languages. As Urdu and Sindhi subjects are considered as additional subjects in this material environment.

Mrs Maliha Rafi, English Language head at a reputed Cambridge school of Karachi "Generations", thinks that $\mathrm{O}$ and A level students display meager interest in Urdu as compared to English. Moreover, it is also evident from the syllabus outline changes and workshops that Cambridge board does not put in as much effort in refining the subject of Urdu as in English. 


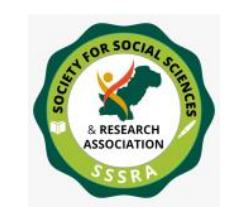

Diminishing local languages in the era..

Anila Joyo, a Sindhi language Teacher in a private school "The Country School", expresses the same concerns of disinterest from students for the language. The decades old syllabus and orthodox teaching method could be held responsible for this, she thinks. We can add Poetry, dramas and we can introduce the prominent Sindhi leaders who fought restlessly at the time of independence but our authorities are not willing to do so, she added.

We approached another teacher Ms Anoshay Jamali a Teacher from Kohat (The Glitters School). She informed us that although teaching of Pashto language is supposed to be compulsory by the Provincial government but majority of the Schools are not following these instructions. Therefore the younger generation are not well aware about the literature, prose, poetry, drama and classic music and about the prominent Pashto Scholars.

It is high time that the government and the civil society take necessary steps to help the native languages flourish, encouraging and motivating the masses to communicate in their own native languages with great pride and without any hesitation. It is also necessary to promote the local languages on national basis, which is definitely possible on account of the social media and the national television. To start with, children should be educated in their mother tongue, before embarking them on foreign languages, which are not even their second but third languages.

\section{Conclusion}

Cultural globalization is playing a key role in disassociating people from their own culture by promoting and artificially injecting the culture or language of one nation in others. The bombardment of cultures is actually disturbing to the homogeneity of a society and finally-- their unity. Cultural globalization is actually responsible in diminishing the local or indigenous languages throughout the world and Pakistan is no exception.

Pakistan is a culturally rich and diversified country. Ours is a multilingual country but unfortunately, the government and speakers of local languages because of the requirement of a globalized capitalist system are not at all interested to promote the native languages to their next generation. Due to the influence of Capitalism, English is already being considered as the de facto lingua franca or global language. An estimated $85 \%$ of International Organizations use English as their Business Language 


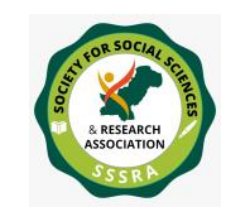

Pak. Journal of Int'L Affairs, Vol 3, Issue 2 (2020)

Diminishing local languages in the era..

The indigenous local languages of Pakistan have never been given importance or highly regarded as important cultural assets. Government has never taken any serious steps or formulated any policy to nourish and nurture the local languages of Pakistan. It is never considered to use as a sword in raising the education standard, in accelerating the economic activity and in creation of a responsible culturally rich nation. Consequently, current and future generations of Pakistan increasingly fail to appreciate and conserve their local languages. All mainstream domains like education, media, films, business or government offices promote English language in their routine business. Unfortunately, we are failed to produce local content for entertainment in local languages, from Pakistani cinemas Hollywood movies are earning huge amounts. Foreign film Industry is playing a prominent role in creating huge impact and invading the minds of the common people, one of the greatest examples of this invasion is Hollywood Film Industry, which produces a variety of films throughout the year.

Educationists strongly put up with the view that these languages play a positive role in the economic development of a country, and there are plenty of evidences available to support the concept that children in their early years of schooling better understand and grasp the concepts that are taught in their mother tongue. Hence, the disintegrating importance of indigenous local languages due to globalization, ensures that the people who speak these languages are always way behind others in means of education, culture, etc. In other words, countries like Pakistan will always be a step behind the western powers because of their inability to acknowledge and nourish their own languages and culture. 


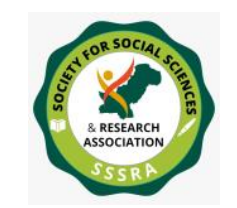

Pak. Journal of Int'L Affairs, Vol 3, Issue 2 (2020)

Diminishing local languages in the era..

\section{References}

Albrow, M. (1990). Globalization, Knowledge and Society. Sage.

Al-Johari. (1991). Child and Society Conditions . Alexandra : Dar Almarefah, 257.

Al-Rodhan, N. R. (2006). Definitions of Globalization: A Comprehensive Overview and a Proposed Definition. Switzerland: Geneva Centre for Security Policy.

Appadurai, A. (1990). Disjuncture and Difference in the Global cultural economy. Theory, culture \& Society, 7(2-3), 295-310.

Arku, J. (2014, June 3). We Need To Encourage Children To Learn In Local Dialect. Graphic Online. https://www.graphic.com.gh/news/general-news/we-need-toencourage-children-to-learn-in-local-dialect-education-minister.html.

Barančicová, J., \& Zerzová, J. (2015). English as a Lingua Franca used at International Meetings. Journal of Language and Cultural Education, (3), 30-51.

Blench, R. (2008). The languages of the Tasmanians and their relation to the peopling of Australia: Sensible and wild theories. Australian Archaeology, 67(1), 13-18.

Canclini, N. G. (1990). Culturas Híbridas: Estrategias Para Entrary Salir De la Modernidad. México: National Institute for Culture and Arts.

Dad, A. A. (2011). Domaaki: A Vanishing Voice. Pamir Times.

Davies, L. (2009, Feb 20). Words of warning: 2500 Languages Under Threat WorldWide As Migrants Head for City. Paris: The Guardian.

Davis, W. (2001). Light at the Edge of The World. Vancouver: Douglas \& McIntyre.

Day Translations. (2018). Endagered Langauges And Why Do They Face Extinction. https://www.daytranslations.com/blog/face-

extinction/\#: :text=From $\% 20 \mathrm{a} \% 20$ state $\% 20$ of $\% 20$ endangerment,more $\% 20$ powerful $\%$ 20or\%20larger\%20group.

Decker, K. D. (1998). Languages of Chitral. Islamabad: National Institute of Pakistan Studies. (Doctoral Dissertation) Quaid-i-Azam University. 


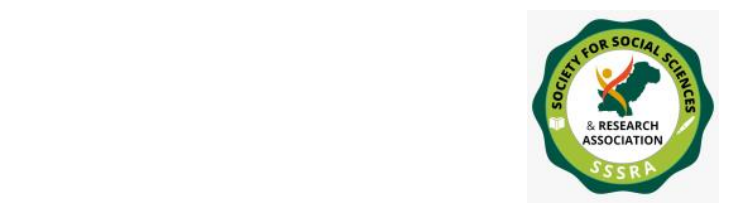

Deleuze, G., \& Guattari, F. (1972). Anti-Oedipus (Vol. 1) of Capitalism and Schizophrenia), trans. Hurley R, Seem M and Lane HR. New York: Continuum. Desk, W. (2018, March 1). Badeshi - An 'Extinct' Language Spoken by only three People. Dunya News.

Dubrow, R. T. (2002, April 25). World Languages are Fast Disappearing Global policy forum.

https://www.globalpolicy.org/component/content/article/162/27570.html.

Eberhard, D. M. (2020). Ethnologue: Language of the World: Dallas, Texas: SIL International. https://www.ethnologue.com/guides/continents-most-indigenouslanguages

Endanger Language Project. (1998). Bhaya. Language Matedata.

http://www.endangeredlanguages.com/lang/3909

Ettlinger, M. (2014, July 07). Here's Why The World Can Never Have One Universal Language. Business Insider. https://www.businessinsider.com/why-there-wont-be-auniversal-language-2014-7.

Galtung, J. (1969). Violence, Peace, and Peace Research. Journal of Peace Research, 6(3), 167-191.

Guillén, M. F. (2001). Is Globalization Civilizing, Destructive Or Feeble? A Critique of five key debates in the social science literature. Annual Review Of Sociology, 27(1), 235-260.

Held, D., \& McGrew, A. (2000). The Global Transformations Reader (Vol. 13). Cambridge: Polity Press.

Khan, A. M., \& Arif, I. (2009). Media Imperialism and Its Effects On Culture Of Pakistan, A Case Study Of Youth Of Multan. Global Media Journal, 2(1), 1-15.

Khawar, Z. (2019, April 27). Box Office: 'Avengers: Endgame' shatters all records in Pakistan. Galaxy Lollywood. http://galaxylollywood.com/2019/04/27/box-officeavengers-endgame-shatters-records-in-pakistan/ 


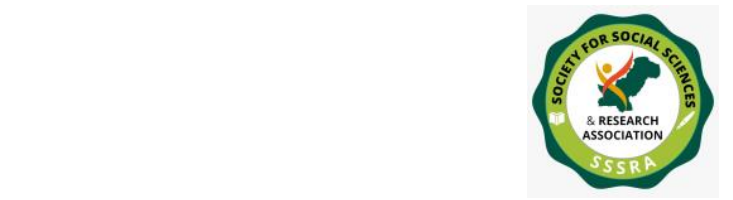

Pak. Journal of Int'L Affairs, Vol 3, Issue 2 (2020)

Diminishing local languages in the era..

Lewis, E. G. (1982). Movements and Agencies of Language Spread: Wales and the Soviet Union compared. Language Spread: Studies in Diffusion and Social Change, 214-259.

Mahmood, S., \& Masud, M. (2019). Understanding the Diffusion and Consumption of American Popular Culture in Pakistan. Journal of Media Studies, 34(1).

Manan, S. A., David, M. K., \& Dumanig, F. P. (2015). Disjunction between language policy and children's sociocultural ecology-an analysis of English-medium education policy in Pakistan. Language and Education, 29(5), 453-473.

Martell, L. (2007). The Third Wave In Globalization Theory. International studies review, 9(2), 173-196.

Mock, J. (n.d.). Dards, Dardistan, and Dardic: an Ethnographic, Geographic, and Linguistic Conundrum. http://www.mockandoneil.com/dard.htm

Nye Jr, J. S. (2002). The Information Revolution and American Soft power. Asia Pacific Review, 9(1), 60-76.

Onuf, N. (2017). Center-Periphery Relations: What Kind of Rule, and Does It Matter? All Azimuth: A Journal of Foreign Policy and Peace, 6(1), 5-16.

Pakistan Bureau of Statistics (2017). Newspapers and Periodicals by Language and Province . Islamabad: Pakistan Bureau of Statisitcs, Government Of Pakistan. https://www.pbs.gov.pk/sites/default/files//tables/rename-as-per-tabletype/Newspaper\%20language.pdf.

Pakistan Bureau of Statistics (2020). Films Released in the Country by Language. Islamabad: Pakistan Bureau of Statistics, Government of Pakistan.

Pakistan Bureau of Statistics (2020). Population By Mother Tongue. Islamabad: Pakistan Bureau of Statistics, Government of Pakistan. http://www.pbs.gov.pk/content/population-mother-tongue.

Parekh, R. (2010, July 19). Burushaski is a strange language. Dawn.

Parekh, R. (2018, January 2). Some Endagered Pakistani languages. Dawn.

Press, C. U. (n.d.). Meaning of Language in English. Cambridge Dictionary: https://dictionary.cambridge.org 
Rahman, T. (2008). Language Policy, Multilingualism and Language vitality in Pakistan. In A. Saxena \& L. Borin (Ed.), Lesser-Known Languages of South Asia (pp. 73-106). Berlin, New York: De Gruyter Mouton. https://doi.org/10.1515/9783110197785.1.73

Rajeev, D. S. (2018). An Analytical Study on Death of a Languages. International Research Journal of Humanities, Language and Literature, 1-12.

Rehman, T. (2010). Languageand Children'seducation In Pakistan. National Institute Of Pakistan Studies, 1-42.

Robertson, R. (1992). Globalization: Social Theory and Global Culture (Vol. 16). Sage.

Sagar, M. Z. (2018, Febuary 5). The Past and present of Gawri language. We Mountain. https://wemountains.com/02/05/353/.

UNESCO. (2017). Endangered Languages. United Nations Educational. Scientific and Cultural Organization. http://www.unesco.org/new/en/culture/themes/endangeredlanguages/faq-on-endangered-languages/

UNESCO. (2010). UNESCO Atlas of the World's Languages in Danger. United Nations Educational. Scientific and Cultural Organization. http://www.unesco.org/languages-atlas/index.php

UNRIC. (2018, Feburary 21). Half of the World's Languages Are Dying. United Nation Regional Information Centre. https://www.unric.org/en/latest-un-buzz/30964half-of-the-worldas-languages-are-dying.

Waters, M. (2009). Globalization : Key ideas. (2nd ed.). London: Routledge.

Woodbury, A. C. (n.d.). What Is an Endangered Language? Linguistic society of America: Advancing the Scientific Study of Language since 1924. https://www.linguisticsociety.org/sites/default/files/Endangered_Languages.pdf. 